\title{
Factors influencing adoption of improved structural soil and water conservation measures in Eastern Ethiopia
}

\author{
Muluken G. Wordofa ${ }^{*}$ (D), Eric N. Okoyo ${ }^{1}$ and Eliso Erkalo ${ }^{2}$
}

\begin{abstract}
Background: Agriculture remains to be the leading sector that contributes enormously to economic development in Ethiopia. Despite its significant contribution to livelihoods, the sector faces persistent challenges due to depletion of natural resources and soil erosion that resulted in diminishing crop and livestock productivity. In order to curb the effects of land degradation, the Government of Ethiopia has been taking serious measures to expand Soil and Water Conservation (SWC) practices throughout the country. Despite the efforts made, the adoption of new practices by farmers have been generally low. This study was aimed at assessing factors influencing smallholder farmers' decision on the use of improved structural SWC practices in Haramaya district, eastern Ethiopia. A multi-stage sampling technique was used to select 120 farm households and 248 plots. A structured interview schedule was used to collect primary data. Descriptive and inferential statistics and Multinomial Logit (MNL) regression model were used to analyze the data.

Results: The key findings showed that a host of socio-demographic, economic and institutional factors significantly affected smallholders' decision to adopt improved structural SWC. In this study, we found that education, farming experience, plot area, distance of the plot from dwelling unit, number of economically active household members, and extension contact were the significant predictors of using improved SWC structures.

Conclusions: Based on our findings, we concluded that improved SWC measures should be scaled up through a concerted effort of extension workers, local administration and other relevant non-state actors. In particular, the extension system should encourage rural communities on sustainable management and use of natural resources. Moreover, the need to create learning opportunities through facilitating appropriate educational and training programs for farmers and focusing on proper management of available economically active household members should be emphasized.
\end{abstract}

Keywords: Soil erosion, Structural SWC measures, Adoption, Smallholder farmers, Multinomial Logit, Ethiopia

\section{Background}

Agriculture remains to be the leading sector that contributes enormously to economic development in Africa (Belachew et al. 2020; Collier and Dercon 2014). More importantly, throughout the Sub-Saharan Africa (SSA)

\footnotetext{
*Correspondence: mgw.tud@gmail.com

${ }^{1}$ Department of Rural Development and Agricultural Extension,

Haramaya University, P.O.Box 138, Dire Dawa, Ethiopia

Full list of author information is available at the end of the article
}

region, the sector is hailed as the main engine of economic growth and poverty reduction. Despite its significant contribution to livelihoods, the sector faces a persistent challenge due to depletion of natural resources and soil erosion (Belachew et al. 2020; Kagoya et al. 2017), climate change induced phenomena, and scarcity of modern/productive inputs, to mention but a few. As an agrarian nation, Ethiopia's fast-growing economy is facing similar challenges due to lingering soil erosion and land degradation (Asnake et al. 2018; Fontes 2020). This 
has resulted in reduced crop and livestock productivity and increased food insecurity and poverty.

Soil degradation especially in the highlands of Ethiopia continues to be a serious threat to subsistence agriculture, which is the backbone of the economy. It has to be noted that $90 \%$ of the population lives in the highlands where land is continually cultivated and, as a result, is highly prone to soil erosion and land degradation (Daniel and Mulugeta 2017). The situation in Haramaya district, the study area, is not different from the rest of the country. Haramaya district faces food production problems, mainly due to physical and man-made causes. The manmade problems include overgrazing, overcultivation, deforestation and inappropriate agricultural practices. The physical factors include climate change, intensity of rainfall, topography and others. These have resulted in enormously degraded land, which seriously threatens smallholders' welfare in the district.

In order to curb the effects of land degradation, the Government of Ethiopia (GoE) has been taking serious measures. One of the strategies has been expanding SWC practices throughout the country (Adimassu et al. 2014). The GoE, through its Productive Safety Net Program (PSNP) and other initiatives, has been promoting terracing, soil and stone bund, mulching, composting etc. to individual and communal lands (Yitayal and Adam 2014). Such practices are proved to be effective in reducing soil erosion and improving soil nutrient availability (Haregeweyn et al. 2015). However, the effectiveness of the government's efforts to promote improved structural SWC measures has not been adequately studied across the various agro-ecological zones of the country. Hence, a scanty empirical evidence exists on the status of adoption and impact of improved structural SWC measures across various contexts.

Recent empirical investigations highlight the usefulness of SWC practices in enhancing productivity and improving smallholder livelihoods (e.g., Haregeweyn et al. 2015; Karidjo et al. 2018). Nevertheless, in spite of the efforts made to popularize the use of such measures, adoption and wider usage is not widespread among farmers in Ethiopia (Asnake et al. 2018; Kirubel and Gebreyesus 2011). This is partly due to lack of active participation of smallholders. In Haramaya district, both traditional and modern SWC structures have been practiced by some farmers, but not to a satisfactory level. More importantly, the rate of adoption of improved structural SWC practices in the district has not been sufficient enough to safeguard smallholder livelihoods against crop loss, food insecurity and abject poverty.

There are several studies documenting the sociodemographic, economic, institutional and biophysical factors that influence farmers' decision to use improved agricultural technologies (for instance, Daniel and Mulugeta 2017; Yitayal and Adam 2014). However, research on adoption of improved SWC practices among smallholders are limited. In Haramaya district, such studies have not yet been sufficiently conducted to provide policy-informative recommendations. Such investigations are vital for selecting relevant conservation methods and interventions to encourage active participation as well as designing and implementing appropriate policies and strategies (Asnake et al. 2018). Therefore, the current study was conducted to identify factors affecting adoption of improved structural SWC practices among smallholder farmers in the study area.

\section{Methods}

\section{Description of the study area}

This study was conducted in Haramaya district which is located at a distance of $510 \mathrm{~km}$ away from Addis Ababa along the main road towards Harar town. It is one of the 19 food insecure districts of east Hararghe zone of Oromia regional state. It has 33 rural kebeles. The district lies between $9^{\circ} 09^{\prime}$ and $9^{\circ} 32^{\prime} \mathrm{N}$ latitude and $41^{\circ} 50^{\prime}$ and $42^{\circ}$ $05^{\prime} \mathrm{E}$ longitude to the west of Harar town. It is bordered by Dire Dawa Administrative Council in the north, Kombolcha district in the north east, Harari Peoples' National Regional State in the east, Fedis district in the south east, Kurfachele district in the south west and Kersa district in the west. From the total area of $521.63 \mathrm{~km}^{2}, 36.1 \%$ is arable or cultivable, $2.3 \%$ is pasture, $1.5 \%$ is forest, and the remaining $60.1 \%$ is considered built-up, degraded or otherwise unusable. Of its total area, $90 \%$ is mid-highland while the remaining $10 \%$ is lowland (Haramaya District Agricultural and Rural Development Office (HDARDO) 2014).

The total population of the district was 271,018 , of which 138,282 were men and 132,736 were women; with an average family size of five. The majority of the population (96.7\%) are Muslims, while $2.7 \%$ of the population practices Orthodox Christianity, and is the remaining following other religions. The predominant soil types of the district are Rigo soils (Haramayan series-60\%) and heavy black clay soils (Vertisols-40\%). The soil texture of the district is sandy loam (HDARDO) 2014).

Rainfall in the district is bimodal, and the mean annual rainfall is $492 \mathrm{~mm}$ ranging from $118 \mathrm{~mm}$ to $866 \mathrm{~mm}$. The short season (Badheessa), usually starts in March and ends in May, and the long season (Ganna) occurs between June and September. Relative humidity varies from 60 to $80 \%$. Minimum and maximum annual temperatures range from $6{ }^{\circ} \mathrm{C}$ to $12{ }^{\circ} \mathrm{C}$ and $17{ }^{\circ} \mathrm{C}$ to $25^{\circ} \mathrm{C}$, respectively (Haramaya District Finance and Economic Development Office (HDFEDO) 2014). 
Agriculture is the mainstay of the population of the district. It is carried out by those who have land and livestock. Some landless are engaged in sharecropping and other non-agricultural income generating activities like daily laboring, petty trading etc. The dominant crops grown in the district are sorghum, maize, potato, sweet potato, haricot beans, vegetables and khat. Vegetables and khat are the two major cash crops grown in the area (HDARDO 2014).

Food crops commonly assume poor production status because of the fragmentation of land, shortage of motor pumps and diversion of attention to the cash crop khat. Livestock are also valuable components of the farming system contributing enormously to achieving household food security. The major livestock production practices are: cattle production for milk, animal fattening, small ruminants (sheep and goat), poultry, and donkey for transport facility. The main problems in the district's livestock production are shortage of feed because of over degradation and scarcity of grazing lands (HDARDO 2014).

Agricultural extension services are important to assist farmers by identifying and analyzing their production problems and by making them aware of opportunities for improvement. It plays significant role in increasing crop production by promoting the use of improved seeds, fertilizers, chemicals and other improved farming practices. Currently, the focus on the extension services in the district is on crops, livestock and natural resources in an integrated development approach. There are 126 Development Agents (DA), who live within the Kebeles (i.e., lowest administrative units) and provide extension services to the farmers. The farmer-DA ratio is one important issue, which needs attention (HDARDO 2014).

\section{Sampling technique}

A multi-stage sampling technique was used to select study sites and draw households for the study. First, Haramaya district was selected purposively due to the high soil erosion problem. Then, three Kebeles were selected randomly. Finally, Probability Proportional to Size (PPS) and simple random sampling were used to draw sampled households from each Kebele. To identify households, a list of names of the household heads was taken from the District Office of Agriculture and Natural Resources as well as the records of DAs. In all the sampled Kebeles the upper, middle and lower slope reaches of the watershed were covered during data collection. This study applied a simplified formula provided by Yamane (1967) to determine the required sample size.

$$
n=\frac{N}{1+N(e)^{2}}
$$

where: $\mathrm{n}$ is the sample size,

$\mathrm{N}$ is the population size, and

$\mathrm{e}$ is the level of precision (0.09).

Based on this formula a total of 120 sample households and 248 plots were used in this study (Table 1).

\section{Data collection and analysis}

Both qualitative and quantitative data were collected from primary and secondary sources through field observation, structured interview schedule, and Focused Group Discussions (FGDs). Qualitative data were collected from elders, selected farmers and key informants, who have adequate knowledge and information about the past and present condition of the study area. The knowledge and information from these sources include natural resources, agricultural production, land use, land management practices, causes, extents, and consequences of soil erosion, SWC practices, local labor organization and institutional support. The quantitative primary data include household characteristics (age, education, farming experiences, family size, marital status), farm characteristics (number of plots, source of farm plot, slope, soil fertility, soil colour, farm size, distance of farm plots from home), perception on soil erosion, causes, extents and consequences of soil erosion, SWC practices, labor availability, land tenure issue, agricultural extension and credit. Secondary data were reviewed from published and unpublished sources.

Qualitative data were analyzed through interpretation and conceptual generalization. For quantitative data, both descriptive statistics and the standard Multinomial Logit (MNL) model were implemented on STATA 11 software. The MNL model was used in this study to assess factors affecting farmers' adoption of improved SWC practices because the dependent variable takes more than two values: (1) traditional or no conservation strategy, (2) improved soil bund, (3) improved stone bund, and (4) improved check dam. Households and plots were used as units of analysis because the focus of the study was on SWC technologies that were observed at the plot level

\section{Table 1 Distribution of sampled household heads by Kebele}

Source: Own survey, 2017

\begin{tabular}{lcc}
\hline List of Kebeles & Total household heads & $\begin{array}{l}\text { Sampled } \\
\text { household } \\
\text { heads }\end{array}$ \\
\hline Kersa Getete & 766 & 37 \\
Damota & 1074 & 51 \\
Finkle & 667 & 32 \\
Total & 2507 & 120 \\
\hline
\end{tabular}


and the dependent variable was also measured at the same level. This level of analysis is advantageous because it captures more spatial heterogeneity and also helps to control for plot level characteristics and hence helps to minimize the omitted variable bias that would confound household level analysis (Saratakos 1999).

Investigating the factors affecting farmers' decision on adoption of improved SWC technologies inherently requires a multivariate analysis. Attempting bivariate modeling excludes useful economic information contained in the interdependent and simultaneous adoption practices (Wagayehu and Drake 2003). However, the use of such bivariate models to analyze factors affecting farmers' decisions to adopt technologies and best practices is still prevalent. For instance, in a recent study in Kenya and Ethiopia, Ng'ang'a et al. (2020) used Probit model to understand factors influencing farmers' decision on soil carbon sequestration. Likewise, binary Logit model was used in a study that looked into determinants of adoption of SWC in Ethiopian highlands (Mekuria et al. 2018). Asfaw and Neka (2017) also implemented binary Logit to find out the predictors of adoption of SWC measures in Wereillu district, Northern Ethiopia. Other empirical works related to adoption of SWC measures that employed binary choice models (i.e., Logit/Probit) include Moges and Taye (2017) in NorthWestern highlands of Ethiopia; Nahayo et al. (2016) in northern Rwanda; Mango et al. (2017) in Malawi and Zambia; Kimaru-Muchai et al. (2020) in Kenya; Kagoya et al. (2017) in central Uganda; and, Lasway et al. (2020) in Tanzania. There are also empirical studies that used Ordered Probit (Teshome et al. 2016), Multivariate and Ordered Probit (Kpadonou et al. 2017), Poisson regression (Darkwah et al. 2019), and Random Parameters Logit (RPL) model (Tarfasa et al. 2018) to analyze farmers' choice of/preference for soil and water management in various developing countries.

In our investigation, it was more appropriate to treat adoption of improved SWC measures as a multiple choice decision. Hence, a MNL model was used to estimate the coefficients and marginal effects of farmers' adoption of improved soil bund, improved stone bund, and improved check dam in the study area. The use of such models is not uncommon in adoption studies with a dependent variable that has many categories. For example, Sileshi et al. (2019) employed a Multivariate Probit model to analyze the determinants of adoption of SWC measures in Deder, Goro Gutu, and Haramaya districts of eastern Ethiopia. A similar model was also used in a very recent study investigating factors affecting adoption of SWC practices in northwest Ethiopian highlands (Belachew et al. 2020). Mengistu and Assefa (2019) also used Multivariate and Ordered Probit to understand farmers' decision process associated with watershed management in Gibe basin of southwest Ethiopia. Further, Multinomial Logit (MNL) was used to assess determinants of smallholder farmers' decision in the Muger Sub-basin of the Upper Blue Nile basin of Ethiopia (Amare and Simane 2017).

In this study, adoption is regarded as the existence of one or more improved structural SWC structures on farmers plot. The independent variables, hypothesized to have relationship with the dependent variable, were carefully chosen based on previous empirical research (Table 2).Prior to running our MNL model, as recommended by Gujarati (1995) multicollinearity problem among continuous explanatory variables was assessed using Variance Inflation Factor (VIF) and Tolerance Level (TOL). Similarly, in order to see the degree of association among dummy and discrete variables, Contingency Coefficient (CC) was computed. The result of these tests

Table 2 Independent variables and descriptive statistics Source: Own analysis from survey data, 2017

\begin{tabular}{|c|c|c|}
\hline Variables & Mean & $\begin{array}{l}\text { Standard } \\
\text { deviation }\end{array}$ \\
\hline Sex (male) $)^{\mathrm{a}}$ & 85.00 & \\
\hline Education level (years) & 2.10 & 2.70 \\
\hline Farming experience (years) & 23.48 & 12.30 \\
\hline Family size (number) & 5.90 & 2.10 \\
\hline $\begin{array}{l}\text { Economically active household members } \\
\text { (number) }\end{array}$ & 2.37 & 0.10 \\
\hline Area of the plot (ha) & 0.44 & 0.17 \\
\hline \multicolumn{3}{|l|}{ Slope of the plot ${ }^{a}$} \\
\hline Flat/gentle & 15.70 & \\
\hline Medium & 39.80 & \\
\hline Steep & 44.50 & \\
\hline \multicolumn{3}{|l|}{ Distance of the plot from dwelling ${ }^{a}$} \\
\hline$<5 \min$ & 14.10 & \\
\hline $5-10 \mathrm{~min}$ & 39.50 & \\
\hline $10-20 \min$ & 31.00 & \\
\hline$>20 \min$ & 15.40 & \\
\hline Security of tenure (yes) ${ }^{a}$ & 90.80 & \\
\hline \multicolumn{3}{|l|}{ Livestock holding (TLU) ${ }^{\mathrm{a}}$} \\
\hline Less than 1 & 7.50 & \\
\hline $1-3$ & 43.30 & \\
\hline More than 3 & 49.20 & \\
\hline \multicolumn{3}{|l|}{ Off-farm activities ${ }^{a}$} \\
\hline Never engaged & 65.80 & \\
\hline Petty trade & 29.20 & \\
\hline Wage labor & 5.00 & \\
\hline \multicolumn{3}{|l|}{ Extension contact ${ }^{a}$} \\
\hline Once/month & 42.50 & \\
\hline Twice/month & 40.00 & \\
\hline$>2 /$ month & 17.50 & \\
\hline
\end{tabular}

a Per cent (proportions) 
showed the absence of multicollinearity problems in the dataset.

\section{Result and discussion \\ Descriptive results}

The results of descriptive analyses on personal and demographic, economic, biophysical, institutional and behavioral characteristics of the sampled farm households is given in Table 2. The results showed that $85 \%$ of the respondents are male household heads who possess a very low level of education. However, they have large family size (six, on average) and rich farming experience (23 years, on average). It is widely acknowledged that family size and composition affect the amount of labor available for farm, off-farm and household activities. It also determines the demand for food. Similarly, more experienced farmers are found to be able to identify soil erosion problems better than less experienced farmers (Shiferaw and Holden 2008).

Looking at the economic variables, the data showed that only $34.2 \%$ of the sample households are engaged in off-/non-farm activities. Off-/non-farm activities have served farmers in the study area as sources of additional income to purchase food crops mainly and other non-food commodities. Involvement in petty trading and wage labor accounted for 29.2 and $5.0 \%$ of off-farm employment opportunities, respectively. Majority of the respondents (about 93\%) possess livestock (TLU). Number of economically active household members who live in and work for the household also determines the labor available in the household which in turn may determine the type of SWC measures used by the farm households. Households with abundant labor may decide to use conservation measures which require more labor force but are effective and efficient.

Concerning biophysical characteristics, it is unquestionable that SWC measures require some area that would have been used for cultivation (growing) of crops or allocated for other purposes. Hence, it is assumed that farmers with larger farm plot area are more likely to use improved SWC measures to reduce soil erosion and conserve water in their farm plots than farmers with small farm plots (Semgalawe 1998). The survey result showed that the average size of farm plot for the sample households is $0.43 \mathrm{ha}$. This indicates that there is a serious shortage of farmland in the study area. Slope is one of the farm attributes that can aggravate land degradation in general and soil erosion in particular. Farmers who have farms in areas which are more prone to soil erosion are expected to experience more soil erosion and therefore recognize the impact of topsoil loss more easily than farmers with farms located on gentle slopes. In this study, $15.7 \%, 39.8 \%$, and $44.5 \%$ plots were located on flat, medium and very steep slopes, respectively. It is expected, thus, that the steeper the slope of the farmland, the higher the probability of the farmers to adopt improved SWC technologies. Distance between farm plots and a homestead is important in which a considerable amount of time can be lost in walking long distances. In addition, it is easier for farmers to take care of their farm and to construct and maintain structural SWC practices and for manure application on the fields near their homesteads than fields that are far away. As it is indicated Table 2, about $15 \%$ of the farms are located more than $20 \mathrm{~min}$ away from the homestead. During the FGDs, it was indicated that leaving crop residues on the cultivation field enhances soil fertility. However, when the land is located far away from homestead, other people may take the residues for home use (fuel energy), for animal feed, for fencing and even for sell. Thus, if the farm field is located near the farmhouse, it becomes easier to be managed and can receive better attention.

The issue of tenure security is among the institutional variables considered in this study. Farmers in the study area have four major sources of land. These are (1) inheritance from family, (2) receiving from Kebeles, (3) sharecropping, and (4) renting system. The survey result revealed that more than $90 \%$ of the respondents feel secure about their land holding. Further, it was found that $76 \%$ of the respondents believe that land belongs to the government; $89 \%$ expect to use the land throughout their lifetime; 94\% think that they have the right to inherit the land to their children; and 93\% believe that they can decide to invest on SWC. Land tenure has important implications for agricultural development in general and SWC in particular (Woldeamlak 2006). Land tenure arrangements in rural Ethiopia have undergone frequent changes since the 1974 revolution. The land reform proclamation, "Land-to-the tiller", which proclaimed that land cannot be sold or mortgaged is one in the Dergue regime. Then, in 1995 a new constitution has been enacted. In this proclamation farmers have been given the right to use their land indefinitely but selling or mortgaging of land is still prohibited (Kebede 2006). It is generally concluded that a more secure tenure system provides the necessary incentives for farmers to decide on adoption of SWC measures on their farm plots (Tesfaye 2011).

The other institutional characteristics is contact with Development Agents (DAs). Having good relationship with DAs helps farmers to be aware of improved SWC practices in reducing hazard associated with soil erosion. The DAs can provide technical information and advice as well as training on improved SWC practices. In the survey, we found that about $43 \%$ of the farmers have interacted with DAs at least once a month. 
Farmers' perception on severity and causes of soil erosion During the survey, farmers in the sample were asked to classify their farm plots, depending on their perception of degree of erosion problem (i.e., extent or severity of occurrence of soil erosion on the plots).The respondents were given three alternatives: low, medium and high to indicate the severity of the problem. The findings, depicted in Table 3, showed that majority of the farmers $(45.8 \%)$ experienced frequent and severe soil erosion problem, whereas $41.5 \%$ of the respondents encountered mild/medium soil erosion problems. The remaining $12.5 \%$ respondents characterized the occurrence of soil erosion on their plot as 'low', occasional or limited. A Chi square test was performed to assess the existence or lack of statistically significant difference among the three groups of responses. The result, $\chi^{2}=14.10$ with $\mathrm{p}<0.05$, clearly indicated the existence of significant differences related to farmers' perception on the severity of soil erosion problem they encountered on their farm plots. However, since $87.3 \%$ of the respondents agreed that they experienced medium to high levels of soil erosion, it can be concluded that the threat of soil erosion is real in the study area. Moreover, one can rationally expect majority

Table 3 The distribution of farmer's response by perception on extent and major causes of soil erosion Source: Own analysis from survey data, 2017

\begin{tabular}{lc}
\hline & Per cent \\
\hline Perception of soil erosion severity/extent & \\
Low & 12.50 \\
Medium & 41.70 \\
High & 45.80 \\
Major causes of soil erosion & \\
Cultivation of steep slopes & 35.5 \\
Poor agricultural practices & 29.5 \\
Heavy rainfall & 20.5 \\
Ceaseless cultivation & 14.5 \\
\hline
\end{tabular}

of the farmers to implement some kind of SWC measures to safeguard their farm plots from the adverse effects of soil erosion.

Soil erosion is a naturally occurring process on all land. The agents of soil erosion are water and wind, each contributing a significant amount of soil loss each year in the study area. The role of water in eroding the land is very high during rainy season. On the other hand, wind causes erosion during dry/windy season. Among the interviewed farmers, about $36 \%$ and $30 \%$ ranked cultivation of steep slopes and poor agricultural practices as the main causes of land degradation, respectively (Table 3 ). The respondents also indicated heavy rainfall and continuous cultivation as additional factors contributing to soil erosion in the study area.

\section{Farmers' perception on structural SWC measures}

The variables considered here were related to the respondents' perception towards risks and comparative advantages of SWC technologies. These variables are important factors in influencing households' participation in improved/new SWC practices. The relative superiority of the technologies in terms of their advantages enable farmers to have favorable perception about the technologies, which in turn enhances decision in favor of adoption of the technologies. In order to get essential information and insight concerning farmers' decision on the adoption of improved SWC practices, examining their perception on each practice to which they are employing is quite important. Hence, knowledge of farmers' evaluative perception on technology attributes in the study area is an appropriate issue. In this study, a five-point Likert scale was used for this purpose and the result is depicted in Table 4.

As indicated in Table 4, almost all the respondents indicated that traditional structural SWC measures are more flexible than introduced SWC structures. On the other hand, more than $70 \%$ of the farmers stated that improved

Table 4 Distribution of farmers' perception on structural SWC measures (5-point Likert-scale) Source: Own analysis from survey data, 2017

\begin{tabular}{|c|c|c|c|c|c|c|}
\hline \multirow[t]{2}{*}{ Perception statement } & \multicolumn{5}{|c|}{ 5-point Likert Scale ${ }^{a}$} & \multirow[t]{2}{*}{ Chi square } \\
\hline & SA & A & NO & D & SD & \\
\hline 1. Traditional structural SWC measures are more flexible & 87.5 & 11.7 & 0.8 & 0.0 & 0.0 & 6.89 \\
\hline 2. Improved soil bund increases soil fertility status & 30.0 & 40.9 & 5.0 & 22.5 & 1.6 & $72.05^{b}$ \\
\hline 3. Improved stone bund needs more use of inputs & 39.1 & 54.2 & 1.7 & 5.0 & 0.0 & $16.91^{\mathrm{c}}$ \\
\hline 4. Improved check dam requires continuous maintenance & 29.2 & 61.7 & 2.5 & 4.1 & 2.5 & 10.50 \\
\hline 5. Improved soil bunds are possible to practice on small farm plots & 1.6 & 9.1 & 2.5 & 24.2 & 62.6 & 17.50 \\
\hline
\end{tabular}

a SA Strongly Agree, A Agree, NO No Opinion, DDisagree, SD Strongly Disagree

b , 'Significant at $1 \%$ and $5 \%$ probability level, respectively 
soil bund increases soil fertility; more than $90 \%$ of the sampled households agreed that improved stone bunds need more inputs/materials; and, more than $90 \%$ of the respondents stated that improved check dams require frequent maintenance. These perceptions imply that farmers in the study area are generally ready to implement improved structural SWC measures. This calls for a more concerted effort by the government and other development partners to promote such SWC structures.

\section{Factors affecting use of improved structural SWC measures} The results of the Multinomial Logit (MNL) analysis conducted to assess factors affecting smallholder farmers' adoption of improved structural SWC measures is given in Table 5. The dependent variable, adoption of improved SWC measures, has four categories: (1) traditional or no adoption (base category), (2) improved soil bund, (3) improved stone bund, and (4) improved check dam. The MNL model was run using 248 plots: traditional structures (113), improved soil bund (92), improved stone bund (25), and improved check dam (18). There were 12 explanatory variables that entered into the MNL model.

As can be seen in the lower part of Table 5, the MNL model is significant with a reasonable explanatory ability. Overall, the econometric analysis indicated that educational level, farming experience, number of economically active household members, contact with extension service providers, plot area, and plot distance from dwelling were found to affect farmer's decision on the use of improved structural SWC measures significantly. However, these variables appear to affect the use of one, two or all of the conservation structures at different sign, magnitude and significance level. In what follows, we discuss these significant predictors of farmers' use of improved structural SWC measures in the study area.

\section{Educational level of household head}

Education level of the household head was found to positively and highly significantly associate with the use of improved soil bund, stone bund and check dam. More precisely, our estimation result showed that a one-year increase in education will increase the probability of a household to use improved soil bund, stone bund and check dam by $0.55 \%, 0.3 \%$, and $0.6 \%$, respectively. This result implies that household heads with relatively better formal educational attainment are more likely to use appropriate improved structural SWC practices and they are also able to anticipate the consequences of soil erosion than non-educated farmers. In addition, they have better understanding of their environment and risks associated with cultivation of marginal lands. Our finding is in line with earlier empirical evidence obtained

Table 5 Multinomial Logit (MNL) model estimation results Source: Own analysis from survey data, 2017

\begin{tabular}{|c|c|c|c|c|c|c|}
\hline \multirow[t]{2}{*}{ Variable } & \multicolumn{2}{|c|}{ Improved soil bund } & \multicolumn{2}{|c|}{ Improved stone bund } & \multicolumn{2}{|c|}{ Improved check dam } \\
\hline & Coef. (Std. Err.) & Marginal effect & Coef. (Std. Err.) & Marginal effect & Coef. (Std. Err.) & Marginal effect \\
\hline Sex of household head & $0.45(0.72)$ & 0.0221 & $0.68(0.45)$ & 0.0221 & $0.05(0.08)$ & 0.0036 \\
\hline Education level & $2.64(0.67)$ & $0.0055^{* * *}$ & $2.60(0.58)$ & $0.003^{* * *}$ & $2.47(0.56)$ & $0.006^{* * *}$ \\
\hline Farming experience & $0.29(0.11)$ & $0.006^{* * *}$ & $0.30(0.15)$ & $0.001 * *$ & $0.24(0.15)$ & $0.002 *$ \\
\hline Security of land tenure & $0.37(0.88)$ & 0.008 & $0.83(0.80)$ & 0.0162 & $0.10(0.70)$ & 0.0024 \\
\hline Perception of soil erosion & $1.54(1.26)$ & 0.003 & $0.86(1.41)$ & 0.0129 & $1.68(1.43)$ & 0.037 \\
\hline Extension contact & $1.93(0.94)$ & $0.0052 * *$ & $1.22(0.80)$ & 0.0194 & $0.01(0.70)$ & 0.0002 \\
\hline Livestock holding & $-0.37(0.32)$ & -0.0007 & $-0.31(0.30)$ & -0.0049 & $-0.27(0.23)$ & -0.0062 \\
\hline Plot area & $1.40(0.52)$ & $0.0028 * * *$ & $1.22(0.59)$ & $0.0184^{* *}$ & $1.92(0.53)$ & $0.0426 * * *$ \\
\hline Plot distance & $-0.35(0.37)$ & -0.0007 & $-1.22(0.59)$ & $-0.001 * *$ & $-0.73(0.40)$ & $-0.0165^{*}$ \\
\hline Slop of the plot & $2.11(1.30)$ & 0.0043 & $1.43(1.43)$ & 0.0215 & $-4.44(2.44)$ & -0.000 \\
\hline Off-farm activities & $-3.67(2.31)$ & 0.361 & $-3.83(2.40)$ & 0.070 & $0.24(0.26)$ & 0.0055 \\
\hline $\begin{array}{l}\text { Number of economically } \\
\text { active household members }\end{array}$ & $0.62(0.38)$ & $0.0013^{*}$ & $0.09(0.33)$ & 0.0013 & $2.43(1.49)$ & 0.054 \\
\hline Constant & $-4.75(3.73)$ & - & $-6.85(3.28)$ & - & $-5.08(3.00)$ & - \\
\hline Observations & 248 & & 248 & & 248 & \\
\hline Log likelihood & 118.18 & & 118.18 & & 118.18 & \\
\hline Chi squared & $134.97^{* * *}$ & & $134.97^{* * *}$ & & $134.97^{* * *}$ & \\
\hline Pseudo $R^{2}$ & 0.36 & & 0.36 & & 0.36 & \\
\hline
\end{tabular}

Dependent variable $=$ existence of improved structural SWC structure on the farm plot

$*^{* *},{ }^{* * *}$ significant at $\mathrm{p}<0.1, \mathrm{p}<0.05$, and $\mathrm{p}<0.01$ probability level, respectively 
from different parts of the country (e.g., Anley et al. 2007; Tizale 2007).

Education level of farmers was also found to be strongly associated with their perception to invest in SWC technologies in North-Western highlands of Ethiopia (Moges and Taye 2017). More importantly, our result corroborates the findings of recent studies conducted in Ethiopia that documented the positive and significant effect of education in fostering adoption of introduced SWC measures (Asfaw and Neka 2017; Belachew et al. 2020; Sileshi et al. 2019). Household's educational status was also found to raise awareness about SWC practices as well as enhance their adoption in Southern AfricaMozambique, Malawi and Zambia (Mango et al. 2017). Hence, it is of utmost importance to promote adult education and training among rural communities in order to enable them to make informed decisions pertaining to conservation of natural resources and their sustainable use.

\section{Farming experience}

Farmers' experience in agriculture is another important factor related to the use of improved technologies and best practices. In this study, we found that farming experience of the household head is positively and significantly related to the adoption of improved structural SWC measures in the study area. The result indicates that experienced farmers tend to appreciate the value of improved conservation strategies than non-experienced farmers. In relation to this result, Shiferaw and Holden (2008) asserted that experienced farmers are capable of detecting soil erosion problems more than non-experienced farmers. Similarly, Fekadu et al. (2013) pointed out that those farmers who have better farm experience have high chance of being participants in conservation measures. As observed from our econometric analysis result, a 1 year increase in farming experience increases the probability of farmers' adoption of improved soil bund, stone bund and check dam conservation by $0.6 \%, 0.1 \%$ and $0.2 \%$, respectively. Nevertheless, we exclaim that young and less-experienced farmers should deserve equal, if not more, attention in the process of adoption and diffusion of improved structural SWC measures.

\section{Extension contact}

Extension service on SWC practices was found to have a positive effect on adopting improved soil bund. However, it did not affect the adoption of improved stone bund or check dams. This suggests that extension service providers in the study area need to vigorously embark on the promotion of improved SWC structures. Other stakeholders should also support the diffusion of improved SWC measures by educating, financing and encouraging farmers in the area. Farmers who receive extension message on SWC from Development Agents will be more encouraged to use improved SWC practice on their farm plots than those who do not have the opportunity to interact with extension personnel. Similarly, Yitayal and Adam (2014) and Tizale (2007) reported that households with access to extension services and information have better understanding of land degradation problem and soil conservation practices and hence may perceive SWC practices to be profitable. As observed from the model result, as farmers get extension message/contents on SWC practices, the probability of using improved soil bund increases by $0.52 \%$.

In recent studies, access to extension service was found to have a significant effect on the adoption of SWC practices in different parts of the country: northwest Ethiopian highlands (Belachew et al. 2020; Moges and Taye 2017); Wereillu district, northern Ethiopia (Asfaw and Neka 2017); Gibe basin, southwest Ethiopia (Mengistu and Assefa 2019); Lemo district, southern Ethiopia (Bekele et al. 2018); and, Gusha Temela watershed, Arsi, Ethiopia (Biratu and Asmamaw 2016). Likewise, contact with extension service providers was found to have positive effect on the adoption of SWC measures in Techiman Municipality of Ghana (Darkwah et al. 2019), in Tanzania (Lasway et al. 2020; Shrestha and Ligonja 2015), and in the Rwizi catchment of south western Uganda (Mugonola et al. 2013).

\section{Plot area}

The MNL model result indicated that plot area has a positive and significant effect on the likelihood of adopting all types of improved structural SWC practices. This is because farmers with larger farm plot are more likely to be able and willing to use improved SWC measures to reduce land degradation problems in plots located on sloppy areas. This result is in line with empirical studies that have shown a positive and significant effect of area of a plot on the decision to use conservation measures (for instance, Amsalu and De Graaff 2007; Kassa et al. 2013). Hence, plot size promotes conservation. The result shows that as plot area increases by one hectare, the probability of deciding to use improved soil bund, stone bund and check dam increases by $0.28 \%, 1.84 \%$ and $4.26 \%$, respectively.

Plot size was also found to have a positive effect on farmers' perception to invest in SWC technologies in northwestern highlands of Ethiopia (Belachew et al. 2020; Moges and Taye 2017; Teshome et al. 2016), in eastern Ethiopia (Sileshi et al. 2019), and in Lemo district, southern Ethiopia (Bekele et al. 2018). It was also found to exert a positive and significant effect on the adoption of soil management practices in southwestern Uganda 
(Mugonola et al. 2013) and in West African Sahel (Kpadonou et al. 2017).

\section{Distance of the plot from dwelling}

Distance of the plot from the farmers' dwelling was related negatively with improved check dam and improved stone bund. The result from the model output indicated that as the distance of the plot from dwelling of the household increases by $1 \mathrm{~km}$, the probability of using improved check dam and improved stone bund decreases by $1.65 \%$ and $1 \%$, respectively. This result in line with the findings of Derajew et al. (2013). Plot distance from the homestead was also found to have a negative and significant effect on farmers' perception to invest in SWC technologies in northwestern highlands of Ethiopia (Moges and Taye 2017). It was also found to negatively affect adoption of SWC measures in South Wollo zone, northern Ethiopia (Asfaw and Neka 2017).

\section{Number of economically active household members}

SWC activities demand labor which is a critical problem in a peak period of production and livestock rearing. In this study, number of economically active household members who participate in improved structural SWC was found to positively and significantly relate with adoption of improved soil bund. The model result indicated that as the number of economically active household members increases by one person, the probability of using improved soil bund increases by $0.13 \%$. However, we did not find any significant relationship between this variable and adoption of the other improved structural SWC measures. This result is in line with the findings of Tadesse and Belay (2004). Availability of adequate labour was also found to positively influence farmers' participation in SWC activities in Gusha Temela watershed, Arsi, Ethiopia (Biratu and Asmamaw 2016). In general, household size was also shown to have a positive effect on adoption of SWC in northwest Ethiopian highlands (Belachew et al. 2020), in Gibe basin, southwest Ethiopia (Mengistu and Assefa 2019), in Ghana (Darkwah et al. 2019), and in Kondoa, Tanzania (Shrestha and Ligonja 2015).

\section{Conclusion and policy implications}

Farmers' conservation decisions are shaped by several factors. In order to understand the factors affecting adoption of improved structural SWC measures at smallholder farm level, this study was conducted in Haramaya district of eastern Ethiopia using a randomly sampled 248 plots. Quantitative and qualitative data were collected from primary and secondary sources. The results of the MNL analysis indicated that education level, farming experience, plot area, number of economically active household members, and extension contact were found to significantly affect the use of improved structural SWC strategies on farm plots. Hence, development policy and program interventions designed to enhance agricultural productivity through promoting structural SWC measures in the study area need to take into account these most important variables with respect to the type of innovation and farmers' preference.

The findings of this study showed the importance of education among households' characteristics. Therefore, stakeholders who work on SWC programs and projects should use those educated farmers as models to others in order to demonstrate the importance of improved SWC measures. Likewise, agricultural extension services in the study area have lasted for more than three decades. However, the findings of this study indicated that the contribution of extension service to the adoption of improved conservation technologies by farmers is not satisfactory. Thus, there is a need to emphasize conservation of resources in the existing extension system in order to enhance the use of improved conservation measures by farmers.

The results of the study also indicated that plot area increases the probability of using improved structural SWC measures. Thus, programs working on SWC should focus on farmers having relatively larger farm plots as point of entry to acquaint the practice more by small farm owners. Such model farmers can be used as proponents of improved structural SWC measures. The study also revealed that number of economically active household members has a significant and positive association with improved soil bund adoption. Therefore, extension planners should give attention to proper management of labor in order to attain SWC goals.

Distance of the plot from the household dwelling also showd significant and negative relationship with improved check dam and improved stone bund conservation strategies. Therefore, district development planners and implementers should consider the issue while program planning and implementation to realize the required result. Finally, the result of the study indicated that the farming experience of the household head affects the use of improved SWC measures. Thus, the district bureau of agriculture and natural resources and other relevant stakeholders should focus on farmers having relatively better farming experience in order to scale-up the practices and benefit younger and relatively less experienced farmers through a trickle-down effect.

\section{Abbreviations}

CC: Contingency Coefficient; DAs: Development Agents; FGDs: Focused Group Discussions; GoE: Government of Ethiopia; HDARDO: Haramaya District Agriculture Office; HDFEDO: Haramaya District Finance and Economic 
Development Office; MNL: Multinomial Logit; PSNP: Productive Safety Net Program; SSA: Sub-Saharan Africa; SWC: Soil and Water Conservation; TLU: Tropical Livestock Unit; TOL: Tolerance Level; VIF: Variance Inflation Factor.

\section{Acknowledgements}

The authors would like to thank the respondents, data collectors and local administration in the study area who facilitated the smooth implementation of the research. We are also grateful to the two anonymous reviewers who provided useful comments on the earlier version of the article.

\section{Authors' contributions}

MGW designed the study, analyzed the data and wrote the paper. ENO supervised data collection and analyzed qualitative data. EE also contributed in the design, implementation and analysis of the research. EE designed the questionnaire and helped in data collection. MGW, ENO and EE designed the conceptual ideas of study and its implementation. EE collected and analyzed data. All authors read and approved the final manuscript.

\section{Funding}

Duna district granted study leave and financial support to the third author. This financial support was used in the design of the study and collection, analysis, interpretation of data, and preparation of the draft manuscript. Preparation of the final manuscript was supported by Haramaya University.

\section{Availability of data and materials}

The data that support the findings of this study can be obtained from the corresponding author up on request.

\section{Ethics approval and consent to participate}

Not applicable.

\section{Consent for publication}

Not applicable.

\section{Competing interests}

The authors declare that they have no competing interests.

\section{Author details}

1 Department of Rural Development and Agricultural Extension, Haramaya University, P.O.Box 138, Dire Dawa, Ethiopia. ${ }^{2}$ Duna District Agricultural Extension Promotion Expert and Agricultural Extension Sub- Process Coordinator, Ministry of Agriculture and Natural Resources, SNNPR, Hosaena, Ethiopia.

\section{Published online: 23 June 2020}

\section{References}

Adimassu Z, Mekonnen K, Yirga C, Kessler A (2014) The effect of soil bunds on runoff, soil and nutrient losses, and crop yield in the central highlands of Ethiopia. Land Degrad Dev 25:554e564. https://doi.org/10.1002/ldr.2182

Amare A, Simane B (2017) Determinants of smallholder farmers' decision to adopt adaptation options to climate change and variability in the Muger Sub basin of the Upper Blue Nile basin of Ethiopia. Agric Food Secur 6:64. https://doi.org/10.1186/s40066-017-0144-2

Amsalu A, de Graaff J (2007) Determinants of adoption and continued use of stone terraces for soil and water conservation in an Ethiopian highland watershed. Ecol Econ 61(2-3):294-302

Anley Y, Bogale A, Haile-Gabriel A (2007) Adoption decision and use intensity of soil and water conservation measures by smallholder subsistence farmers in Dedo district, Western Ethiopia. Land Degrad Dev 18:289-302

Asfaw D, Neka M (2017) Factors affecting adoption of soil and water conservation practices: the case of Wereillu Woreda (District), South Wollo Zone, Amhara Region, Ethiopia. Int Soil Water Conserv Res 5(4):273-279. https ://doi.org/10.1016/j.iswcr.2017.10.002

Asnake M, Heinimann A, Gete Z, Hurni H (2018) Factors affecting the adoption of physical SWC practices in the Ethiopian highlands. J Int SWC Resour 6(1):23e30. https://doi.org/10.1016/j.iswcr.2017.12.006

Bekele A, Aticho A, Kissi E (2018) Assessment of community based watershed management practices: emphasis on technical fitness of physical structures and its effect on soil properties in Lemo district, Southern Ethiopia. Environ Syst Res 7(2018):20. https://doi.org/10.1186/s4006 8-018-0124-y

Belachew A, Mekuria W, Nachimuthu K (2020) Factors influencing adoption of soil and water conservation practices in the northwest Ethiopian highlands. Int Soil Water Conserv Res 8(2020):80-89. https://doi.org/10.1016/j. iswcr.2020.01.005

Biratu AA, Asmamaw DK (2016) Farmers' perception of soil erosion and participation in soil and water conservation activities in the Gusha Temela watershed, Arsi, Ethiopia. Int J River Basin Manage 14(3):329-336. https:// doi.org/10.1080/15715124.2016.1167063

Collier P, Dercon S (2014) African agriculture in 50 years: smallholders in a rapidly changing world? World Dev 63(2014):92-101

Daniel A, Mulugeta N (2017) Factors influencing adoption of SWC practices: The case of Wereillu woreda (district), South Wollo zone, Amhara region, Ethiopia. Int Soil Water Conserv Res 5(4):273e279. https://doi. org/10.1016/j.iswcr.2017.10.002

Darkwah KA, Kwawu JD, Agyire-Tettey F, Sarpong DB (2019) Assessment of the determinants that influence the adoption of sustainable soil and water conservation practices in Techiman Municipality of Ghana. Int Soil Water Conserv Res 7(3):248-257. https://doi.org/10.1016/j.iswcr.2019.04.003

Derajew F, Bekabil F, Wagayew B (2013) Determinants of the use of soil conservation technologies by smallholder Farmers: The case of Hulet Ejo Enesie District East Gojjam Zone, Ethiopia. Asian J Agric Food Sci 01 (04), October 2013

Fekadu B, Yenealem K, Jema H, Belaineh L (2013) Impact of integrated soil and water conservation program on crop production and income in West Harerghe Zone, Ethiopia. Int J Environ Monit Analy. 1(4):11-120. https:// doi.org/10.11648/j.ijema.20130104.11

Fontes FP (2020) Soil and water conservation technology adoption and labour allocation: evidence from Ethiopia. World Dev 127(2020):104754

Gujarati DN (1995) Basic econometrics. McGraw-Hill Inc., New York

Haregeweyn N, Tsunekawa A, Nyssen J, Poesen J, Tsubo M, Tsegaye MD, Schött B, Adgo E, Tegegne F (2015) Soil erosion and conservation in Ethiopia: a review. Prog Phys Geogr 39(6):750-774

HDARDO (Haramaya District Agricultural and Rural Development Office) (2014) Woreda annual report for Oromia regional state, Haramaya, Oromia

HDFEDO (Haramaya District Finance and Economic Development Office) (2014) Woreda annual report for Oromia regional state, Haramaya, Oromia

Kagoya S, Paudel KP, Daniel NL (2017) Awareness and adoption of soil and water conservation technologies in a developing country: a case of Nabajuzi Watershed in Central Uganda. Environ Manage 61 (2):188-196. https://doi.org/10.1007/s00267-017-0967-4

Karidjo BY, Wang Z, Boubacar Y, Wei C (2018) Factors influencing farmers' adoption of soil and water control measures in Keita valley, a semi-arid area of Niger. Sustainability 10(288):2e13. https://doi.org/10.3390/su10020288

Kassa Y, Beyene F, Haji J, Legesse B (2013) Impact of integrated soil and water conservation program on crop production and income in West Harerghe Zone, Ethiopia. Int J Environ Monit Analy 1(4):111-120

Kebede M (2006) Farmers'Perception and Determinants of Land Management Practices in Ofla Woreda, Southern Tigray, Ethiopia. M.Sc. Thesis. Alemaya University, Ethiopia

Kimaru-Muchai SW, Ngetich FK, Baaru M, Mucheru-Muna MW (2020) Adoption and utilisation of Zai pits for improved farm productivity in drier upper Eastern Kenya. J Agric Rural Develop Trop Subtrop. 121(1):13-22. https:// doi.org/10.17170/kobra-202002281030

Kirubel M, Gebreyesus B (2011) Impact assessment of soil and water conservation measures at medego watershed in Tigray, Northern Ethiopia. Maejo Int J Sci Technol 5(3):312-330

Kpadonou RAB, Owiyo T, Barbier B, Denton F, Rutabingwa F, Kiema A (2017) Advancing climate-smart-agriculture in developing drylands: joint analysis of the adoption of multiple on-farm soil and water conservation technologies in West African Sahel. Land Use Policy 61 (2017):196-207. https://doi.org/10.1016/j.landusepol.2016.10.050

Lasway JA, Temba GR, Ruhinduka RD (2020) Determinants of soil conservation technologies among small-scale farmers in Tanzania; evidence from national panel survey. Afr J Econ Rev 8(1):89-105

Mango N, Makate C, Tamene L, Mponela P, Ndengu G (2017) Awareness and adoption of land, soil and water conservation practices in the Chinyanja 
Triangle, Southern Africa. Int Soil Water Conserv Res 5(2):122-129. https:// doi.org/10.1016/j.iswcr.2017.04.003

Mekuria A, Heinimann A, Zeleke G, Hurni H (2018) Factors influencing the adoption of physical soil and water conservation practices in the Ethiopian highlands. Int Soil Water Conserv Res 6(1):23-30. https://doi. org/10.1016/j.iswcr.2017.12.006

Mengistu F, Assefa E (2019) Farmers' decision to adopt watershed management practices in Gibe basin, southwest Ethiopia. Int Soil Water Conserv Res 7(4):376-387. https://doi.org/10.1016/j.iswcr.2019.08.006

Moges DM, Taye AA (2017) Determinants of farmers' perception to invest in soil and water conservation technologies in the North-Western Highlands of Ethiopia. Int Soil Water Conserv Res 5(1):56-61. https://doi. org/10.1016/j.iswcr.2017.02.003

Mugonola B, Deckers J, Poesen J, Isabirye M, Mathijs E (2013) Adoption of soil and water conservation technologies in the Rwizi catchment of south western Uganda. Int J Agric Sustain 11(3):264-281. https://doi. org/10.1080/14735903.2012.744906

Nahayo A, Pan G, Joseph S (2016) Factors influencing the adoption of soil conservation techniques in Northern Rwanda. J Plant Nutr Soil Sci 179(3):367-375. https://doi.org/10.1002/jpln.201500403

Ng'ang'a SK, Jalang'o DA, Girvetz EH (2020) Adoption of technologies that enhance soil carbon sequestration in East Africa. What influence farmers' decision. Int Soil Water Conserv Res. 8(1):90-101

Saratakos S (1999) Social Research, 2nd edn. Charles Sturt University, Australia

Semgalawe ZM (1998) Household Adoption Behaviour and Agricultural sustainability in the Northern Mountains of Tanzania: The case of soil conservation in the North pares and Waste Usambara Mountains. Published PhD Thesis, Wageningen University Wageningen, The Netherlands

Shiferaw B, Holden S (2008) Resource degradation and adoption of land conservation technologies in the Ethiopian high lands: a case study in Andit Tid, North Shewa. Agric Econ 18(3):233-247

Shrestha RP, Ligonja PJ (2015) Social perception of soil conservation benefits in Kondoa eroded area of Tanzania. Int Soil Water Conserv Res 3(3):183-195. https://doi.org/10.1016/j.iswcr.2015.08.001

Sileshi M, Kadigi R, Mutabazi K, Sieber S (2019) Determinants for adoption of physical soil and water conservation measures by smallholder farmers in Ethiopia. Int Soil Water Conserv Res 7(4):354-361. https://doi. org/10.1016/j.iswcr.2019.08.002

Tadesse M, Belay K (2004) Factors influencing adoption of soil conservation measures in Southern Ethiopia: the case of Gununno area. J Agric Rural Develop. 105(1):49-62

Tarfasa S, Balana BB, Tefera T, Woldeamanuel T, Moges A, Dinato M, Black H (2018) Modeling smallholder farmers' preferences for soil management measures: a case study from South Ethiopia. Ecol Econ 145(2018):410419. https://doi.org/10.1016/j.ecolecon.2017.11.027

Tesfaye H (2011) Assessment of sustainable watershed management approach: case study in Lenche Dima, Tsegur Eyesus and Dijjil Watershed. MPS Thesis, Cornell University

Teshome A, de Graaff J, Kassie M (2016) Household-Level determinants of soil and water conservation adoption phases: evidence from North-Western Ethiopian highlands. Environ Manage 57(2016):620-636. https://doi. org/10.1007/s00267-015-0635-5

Tizale CY (2007) The dynamics of soil degradation and incentives for optimal management in Central Highlands of Ethiopia. PhD. Dissertation, South Africa: University of Pretoria

Wagayehu B, Drake L (2003) Soil and water conservation decision behavior of subsistence farmers in the Eastern Highlands of Ethiopia: a case study of the Hunde-Lafto area. Ecol Econ 46(3):437-451

Woldeamlak B (2006) Soil and water conservation intervention with conventional technologies in northwestern highlands of Ethiopia: acceptance and adoption by farmers. Land Use Policy 24(2):404-416

Yamane T (1967) Statistics: an introductory analysis, 2nd edn. Harper Row, New York

Yitayal A, Adam B (2014) The impact of SWC program on the income and productivity of farm households in Adama district, Ethiopia. Sci Technol Arts Res J. 3(3):198

\section{Publisher's Note}

Springer Nature remains neutral with regard to jurisdictional claims in published maps and institutional affiliations.

\section{Submit your manuscript to a SpringerOpen ${ }^{\circ}$ journal and benefit from:}

- Convenient online submission

- Rigorous peer review

- Open access: articles freely available online

- High visibility within the field

- Retaining the copyright to your article

Submit your next manuscript at $\boldsymbol{\nabla}$ springeropen.com 